\author{
A. Kaihe ${ }^{1}$ \\ ${ }^{I}$ PhD candidate, Graduate School of Core Ethics and Frontier Sciences \\ Ritsumeikan University, Japan
}

\title{
MANJU NOBLE AND WEST: PRINCE HOŠOI DELENGGE FAMILY
}

\section{Annotation}

There is limited research on the relationship between the Manju aristocrats in the Ch'ing Empire and the West. As the only family in the Ch'ing Empire that continued to focus on Western academic research, the emergence and existence of the Hošoi Delengge Family and the continued cognition and understanding of the Manju Group and the absorption of Western civilization in the history of the Ch'ing Empire should have special era significance and historical reference value. At a time when the research on the history of the relationship between officials and merchants in the coastal Han people and Westerners in the Ch'ing has attracted much attention, the author of this article argues that it is necessary to select Yihui, the third-generation owner of his family, as the research object, and investigate his life experience and personal learning. It analyzes the specific thoughts and academic achievements embodied in the process of understanding Western civilization, combining family history documents and official documents to draw a relatively complete image of the Manju aristocracy who actively learns and absorbs Western civilization. Investigate the formation and development of a handful of academic families among the Manju aristocrats who are minority of foreign races.

Keywords: Manchu elites, absorb Western civilization, modern technology, knowledge dissemination, prospects, innovative thinking, diligent and studious, academic family, absorb advanced civilization, self-examination, Tungus and European

$$
{ }^{1} \text { A. Кайхэ }
$$

${ }^{1}$ Кандидат философских наук, доктор PhD,

Высшая школа фундаментальной этики и пограничных наук, Университет Рииумейкан, Япония

\section{МАНДЖУ БЛАГОРОДНЫЙ И ЗАПАДНЫЙ: СЕМЬЯ ПРИНЦА ХОШОЯ ДЕЛЕНГГЕ}

\section{Аннотация}

Существует ограниченное исследование отнотений между аристократами манджу в империи Цин и на Западе. Как единственная семья в империи Цин, которая продолжала фокусироваться на западных академических исследованиях, появление и существование семьи Хошой Деленгzе, а также продолжающееся познание и понимание группы Манджу и поглощение западной иивилизащии в истории империи Цин должны иметь особое значение эпохи и историческую справочную ценность. В то время, когда исследование истории взаимоотношений чиновников и купцов в прибрежных ханьских народах и западников в Цине привлекло большое внимание, автор этой статьи утверждает, что необходимо выбрать Ихуэя, владельиа семьи в третьем поколении, в качестве объекта исследования и исследовать его жизненный опыт и личное обучение. Он анализирует конкретные мысли и научные достижения, воплощенные в процессе понимания западной цивилизации, комбинируя документы семейной истории и официальные документы, чтобы нарисовать относительно полный образ аристократии Манджу, которая активно изучает и впитывает западную цивилизачию. Исследуйте формирование и развитие горстки академических семей среди аристократов манджу, которые являются меньшинством иностранных рас. 
Ключевые слова: маньчжурские элиты, поглощение западной циивилизаџии, современные технологии, распространение знаний, перспективы, инновационное мышление, прилежные и прилежные, академическая семья, поглощение развитой ичивлизации, самоанализ, тунгусы и европейцьь

\title{
${ }^{1}$ A. Kaйxэ
}

${ }^{l}$ Философия вылылмдарының кандидаты, Іргелі этика және текара гылымдарының Жогары мектебі, Ризумейкан Университеті, Жапония.

\section{МАНДЖУ АСЫЛ ЖӘНЕ БАТЫС: ХАНЗАДА ХОШОЙ ДЕЛЕНГЕНІН ОТБАСЫ}

\author{
Ан̆датпа
}

Цин империясы мен Батыставы манджу ақссүйектерінің қ̧арым-қ̧атынасы туралы шектеулі зерттеулер бар. Цин империясындавы батыстық академиялық зерттеулерге назар аударуды жалгастырван жалгыз отбасы ретінде Хоша Деленгzе Отбасының пайда болуы мен өмір сүруі, сондай-ақ Манджу тобын білу және түсіну және Цин империясының тарихындагы Батыс өркениетінің жұтылуы дәуірдің ерекше мәні мен тарихи анықтамалық құндылыққ̧а ие болуы керек. Жагалаудавы хан халықтары мен Цинь батыстарындавы шенеуніктер мен көпестер арасындавы қарым-құатынас тарихын зерттеу үлкен назар аударван кезде, осы мақаланың авторы зерттеу нысаны ретінде Үшінші буындавы отбасы иесі Ихуэйді таңдап, оның өмірлік тәжірибесі мен жеке окуын зерттеу керек деп санайды. Ол Батыс өркениетін түсіну проиесінде пайда болван нақты ойлар мен вылыли жетістіктерді талдайды, Батыс өркениетін белсенді зерттейтін және сіңіретін манджу ақсүйектерінің салыстырмалы түрде тольқ бейнесін салу үшін отбасылық тарих құжаттары мен ресми құжаттарды біріктіреді. Шетелдік нәсілдердің аз бөлігі болып табылатын манджу ақссүйектерінің арасында бірнеше академиялық отбасылардың құалыптасуы мен дамуын зерттенізі.

Түйін сөздер: маньчжу элиталары, Батыс өркениетін сіңіру, заманауи технологиялар, білімді тарату, перспективалар, инновачиялық ойлау, ынталы және ынталы, академиялық отбасы, дамыган өркениетті сіңіру, интроспекция, тунгус және еуропальқттар

Introduction. This article intends to further reveal the influence of the gradual advancement of Western learning brought by missionaries in the 17th century on the life and culture of prince Hošoi Delengge family. Then clarify the position and historical significance of this family in the study of Ch'ing history. The knowledge of this family will also refresh the understanding of Ch'ing Dynasty's Manchu nobility in the research field of Ch'ing history. so, as to have a more comprehensive and detailed understanding of the philosophical mind map of the central cultural circle of the Ch'ing Empire from the perspective of the Manchu ruler.

\section{Section 1}

There were hundreds of princes in the Ch'ing Empire and over a hundred palaces were built for these families. What is meant by a "families of Manju aristocracy 府邸世家/FuDiShiJia"? The Manchu scholar Jin Qicong defined it as: "'Fu 府" means "Royal Palace"; "Di 邸", commonly known as "Prince Palace", FuDi 府邸 is the collective name of big or small prince palace. The palace of a large family with a position and meritorious service." These elite Manju group had an important influence on politics, literature and art, science and technology in the early period of Ch'ing Empire. The Manju as the ruling class of the Ch'ing Empire is completely different from the previous era Ming Dynasty in terms of national composition, language, letter, customs, clothing, culture, religion, hairstyle, social structure, etc. As a marginalized small power in Northeast Asia, Manju possesses a unique set of ruling system. Since the Ch'ing Empire entered the Shanaha Pass, Manju group become the ruler of the Chinese speaking regime, the Manchu elite group continued to accept the influence of Chinese culture and Western technology, expanded the content of the royal family culture more 
widely. With a vast territory and numerous ruling groups with different linguistic and cultural characteristics, the Ch'ing imperial family attaches great importance to the diversified education of the ruling core children, in order to cultivate successors who can control the empire's complex and different regional groups' cross-cultural governance capabilities. In addition to being proficient in three foreign languages besides Manchu: Mongolian, Chinese, and Tibetan. In order to cultivate the successors of the next generation, the children of the Manju elite received strict training from childhood. In addition to the study of Manchu, Mongol and Sinology, horse archery and other tactical practices. The princes also have the use of various advanced weapons, such as flintlock. The historical facts of Emperor Doro eldengge's skillful use of flintlock guns can confirm the popularity and mastery level of the prince's education of Chinese and Western weapons. ${ }^{1}$. What's more, there are many talents Manju proficient in western technology were active before Emperor Abkai Wehiyehe era ${ }^{2}$. For example, Mingantu 明安图, also known as Sharavyn Myangat ${ }^{3}$. His research achievement about the Catalan sequence was much early than the Westerner.

The brothers who competed with Emperor Hūwaliyasun Tob for the throne held various major military and political positions in the empire at that time ${ }^{4}$. This allowed Emperor Hūwaliyasun Tob to exercise unprecedented control and attack on the imperial family that held military and political positions after he became Emperor. From then on, until the end of the Boxer Rebellion, the royal family numbers were forced to stay away from military and political positions, in order to prevent the reappearance of the cruel internal fighting between the royal family from Nurhachi to Emperor Hūwaliyasun $\mathrm{Tob}^{5}$. However, this measure also restrained and weakened the core strength of the Manju clan. As the imperial princes moved away from important military and political positions in the empire, their chances of contacting the forefront of Western intelligence and affecting the destiny of the empire became smaller.

The emperor's monitoring of royal family members has been greatly weakened in the later period of Emperor Abkai Wehiyehe. Because the heir system formulated by Emperor Hūwaliyasun Tob has changed the tradition of selection by strength, the royal family no longer cares about competition for the throne, but the royal family members interested in Western civilization have become very few.

The First-generation master of Prince Hošoi Delengge family, who named Yongki (17411766), he is the fifth son of Emperor Abkai Wehiyehe (1735-1796) of the Ch'ing. Following the Diversified learning traditions in the Manju court education system, the prince Hošoi Delengge family has studied the Western technique and acknowledgement: astronomy, algorithms, mechanical, and medicine - studies and researched all these field with an open mind.

Yihui (1799-1838), the third-generation owner of this family, is a key figure in inheriting and carrying forward this attitude of communicating with Westerners. Yihui lived in this 'peaceful' period, different from other royal members. Yihui focuses more on comparing the differences between the Empire and the West, understanding and learning West and its technology. At the same time, he pays attention to the relationship between his own class and the common people. These ideas can be read from his anthology. These cognitions of him were inherited from his father and grandfather.

\section{Section 2}

\footnotetext{
1《清史稿 卷十七 本纪十七》十八年九月, 从幸秋狝木兰, 上先还京师, 而教匪林清党犯風之变作。是月

，戊寅，贼入内右门，至养心殿南，欲北窝。上御枪毕二贼，余贼溃散，乱始平。飞章上闻。仁宗欣慰， 封上为智亲王，号所御枪曰“威烈”。谕内阁曰：“忠孝兼备，岂容稍靳恩施。”上谦冲不自满假，谢恩奏言 : “事在仓猝, 又无御贼之人，势不由己，事后愈思愈恐。”其不矝不伐如此。

${ }^{2}$ Emperor Abkai Wehiyehe's philosophy of governance and understanding of civilization are very different from those of the previous three emperors. The archives Annex 1 provide a glimpse of his thoughts. The use of flintlock guns is forbidden, and traditional bows and arrows are required to continue hunting.

${ }^{3}$ Annex 2

${ }^{4}$ Annex 3

5 宮崎（1950）（宮崎（1996）pp.36、44-46、55-56
} 
At the beginning of the 17th century, Jesuit missionaries began to enter the Ming Empire, and they played an objective role in promoting the exchange and development of social culture, science and technology between the Mainland East Asia and the West. Western missionaries tried to win Manju Emperor's hearts through Western learning in order to infiltrate Christianity. The historical fact is that Christianization has not been accepted in Ch'ing society, but these advanced Western technologies, ideas, and systems have profoundly affected Ch'ing and promoted the progress of modern era comes.

The Manju aristocratic society of the Ch'ing Empire, due to its special status, had the opportunity to get in touch with more cultural technology of the Western world earlier though working with missionaries during the period of Emperor Ijishūn Dasan, Emperor Elhe Taifin (16541722) and Emperor Huwaliyasun Tob (1644-1735). Because these three Emperors have placed unprecedented emphasis on Western civilization and applied the technology and knowledge of Western civilization to the practice of imperial rule. At the same time, the missionaries also made extensive contacts with the Manju ruling class, and paid attention to learning Manchu and Chinese in order to gain a deeper understanding of the internal information of the Ch'ing Empire. The Jesuit missionaries introduced Confucian philosophical classics works and Manju language works to Europe, it is providing the West with a steady stream of information about this Eastern Asia empire ruled by the Tatars, so called Manju.

Until Emperor Abkai Wehiyehe came to the throne, the Ch'ing Empire recruited a large number of Western missionaries in various aspects to hold many important positions. Such as the production of precise map and mapping technology, trigonometric geometric function calculations, astronomical observations, development of new firearms, etc.

There are several ways for the aristocracy of the Ch'ing Empire to absorb Western academic resources. First, due to the training requirements in the Royal Community and the influence of missionaries those who service in the court, they began to accept Western languages, cultures and contact Western technology products; Second, through the diplomatic channels of the imperial court. Manju nobles also have convenient conditions for holding official positions to extensive exchanges with Western civilization, especially introduce literature works and publications ${ }^{6}$. Third, Manju nobles have conditions for co-working with Westerners. For example, Yihui's career in the Royal Astronomical Society gave him opportunity to make communication with westerners.

\section{Section 3}

The Prince Hošoi Delengge YongKi(1741-1766), is professional for his achievements in Manchu, Mongolian, Chinese, sinology, history, poetry, calligraphy, and Pythagorean theorem and Western trigonometry. In November 30th year of Abkai Wehiyehe, YongKi was awarded as the Prince Hošoi Delengge in his age 25. YongKi is not limited by cultural regionality, which is in line with the imperial prince's thinking of rapid expansion and growth. ${ }^{7}$

Prince Rongke of the Second Rank, Mianyi (1764-1815), the fifth son of Prince Hošoi Delengge YongKi. Mianyi accompanied Emperor Saicungga Fengšen when he was young, and after the Eight Trigrams uprising of 1813, he suggested that the Emperor Saicungga Fengšen should return to Beijing as soon as possible to stabilize the people, when who was far away from the Rihe Palace, This move was highly praised by Emperor Saicungga Fengšen, it makes Mianyi was particularly favored.

Mianyi is an important figure in passing on the family ideology. Because Yihui, Mianyi's heir, has pushed the family to associate with Westerners and actively absorb Western civilization to a new level, mastering the most advanced Western astronomy knowledge and Latin through the title and position can prove.

Yihui (1799-1838), is the eldest son of Mianyi. In June of the 1815, he inherited Duke Doro Beile, and served as a cabinet minister and commander of the Gulu šanggiyan Ujen coohai army. His main job is to supervise the official education of the aristocracy children of the four Banner armies on

\footnotetext{
${ }^{6}$ Annex 5

7 乾隆四十八年《钦定古今储氮金鉴》〈孝贤皇后所生嫡子为人端重醇良依〉: “其时朕视皇五子于诸子中更 觉贵重，且汉文、满洲、蒙古语、马、步、射及算法等事，并皆涃习，颇属意于彼，而未明言，及复因病 
each side of the Manchu nobility ${ }^{8}$. With multiple positions, he is also in charge of the Imperial Publish Office 武英殿修书处、御书处, supervises the national examination system in the capital area, and oversees the affairs of the observatory and other cultural and technological work. He is in charge of royal education and national examinations in the capital region. He is also in charge of important positions such as the Royal Astronomical Observatory and the legislature.

Yihui's aristocratic status and the position in charge of the Royal Astronomical Society provided him with enough conditions and reasons for contact with the missionaries. These contact further aggravated Yihui's awareness and anxiety about the state of the empire. because he was sober, He realized that Manju Empire is declining, and that Western civilization is rising rapidly. The early three generations ancestors of the Prince Hošoi Delengge Family laid the foundation for the family's open view to the world and the cognition of foreign civilizations, which also made it possible for future descendants to continue to have this positive awareness in different eras and achieve personal growth on different achievements and life realizations.

\section{Section 4.}

The era of Yihui's life is from the end of Emperor Saicungga Fengšen (1796-1820) to the middle of Doro Eldengge (1821-1850) era, many technological products of West appear in the Manju royal circle. Also, many Western objects used in his family daily life, especially the automaton. The Yihui family also has many such mechanical clocks. Some birds or puppets will make sounds or make movements when telling the time on the hour, while others can predict weather changes. Yihui is sensitive to these new productions and he believes that the advantages of Western technology have already surpassed traditional Eastern technology. This is described in Yihui's dairy and literature work. there is a poem titled An Automaton in his anthology:

《明善堂文集·流水篇一》〈自鸣钟〉

“奇绝洋钟制，铜壶巧莫并，枢机对境转，风雨应时鸣。”

MingShanTangWenJi LiuShuiPian $1<$ Automaton >

"How wonderful a Western automaton, with an ingenious shape looks like a copper kettle.The gears of the machine interlock and rotate, and could be forecast weather. "

(All Chinese documents in this article are translated by the author.) He realized that the Eastern timing method was already very backward. He emphasized that the "copper pot hourglass(YuGuan 玉琯 in

"Lü Lizhi《律暦志》a timekeeping instrument in ancient Ch'ing). Yihui also praised in his poem

QianLiJing,<千里镜> that the astronomical telescope can correct the wrong perception of astronomical knowledge in ancient East Asia.

“圆镜五重合，长筒制度匀，谈天古多误，望远此如神。”

" This telescope is combined by five mirrors, The barrel body is smooth and uniform in thickness, with refined craftsmanship. There are many fallacies in the study of astronomy in the ancient East. If you really want to see the constellations in the sky, you have to rely on this magical instrument. " In the eleventh year of Emperor Doro Eldengge of the Ch'ing (1831), Yihui was assigned to manage the Royal Observatory. The observatory was built on the battlement at the southeast corner of Beijing's inner city. It was originally built from the Yehe Yüan Ulus to the 16th year of the Kublai Khan (1279

, the year of Ground Rabbit). The Observatory is responsible for observing the celestial phenomena and promulgating the calendar. The era when the missionaries came to the early Qing Dynasty was when the Emperor Manchuria promoted the conversion of the "traditional oriental astronomical observation method" to the use of "modern western astronomy". Emperor Elhe Taifin fully affirmed Western astronomy and algorithms. The missionaries introduced the advanced astronomical achievements of the time to Ch'ing. Yihui, who was in direct contact with the most advanced Western astronomy technology at the time.

Yihui wrote in his poem as follow when he when he boarded the observatory:

\footnotetext{
${ }^{8}$ The military system of Manju is called Eight Banner(Jukun Gusa), which divided to two wings, there have four banners at each side of the wing.
} 
《明善堂文集 流水编四》登观象台

“暂领羲和职, 初登观象台, 元朝遗古迹, 郭令实雄才, ......仁皇亲制作, 宝器尽珍瑰......抚 辰曾继述，亭午久徘徊。......机祥腐儒婳，洋海异人来，柔远锡嘉号，通微辅圣裁，为邦斯首 务, 推测勉饮哉。”

"Mingshantang Collection and Chapter Four of Flowing Water" <On the Observatory>:

'I was appointed to temporarily manage astronomical affairs and boarded the Observatory for the first time. This is an ancient monument left by the Yuan Dynasty. Astronomer GuoShoujing 郭守敬 is really tallented. . . The astronomical instruments personally supervised by Emperor Elhe Taifin are all really treasures. . . I spent a long time visiting to see each of them one by one to understand its function. It took too long, even after noon. . . Although the instruments are very sophisticated, the managers ${ }^{9}$ of the observatory were not proficient in use and maintenance. Western missionaries come from sea. The emperor attached great importance to talents and technology, and appointed some of proficient Westerner in astronomy to work in the observatory to serve for our Empire. . ' This poem stated that the Emperor Elhe Taifin had appointed Westerners as the Observatory Supervisor and made new instruments on the stage. In the twelve year of Emperor Elhe Taifin of the Ch'ing (1673), six instruments such as the Celestial Globe, the Equatorial Armilla, the Ecliptic Armilla, the Altazimuth, the Azimuth Theodolite and the Sextant were newly made on stage. The old instrument was moved under the stage. Elhe Taifin also lamented the lack of advanced and professional astronomical observational capabilities for the chief observatory officials of the Empire, and the need to recruit Westerners to the department. It also pointed out that astronomy should be improved. In the fifty-fourth year of Emperor Elhe Taifin (1715), the 'horizontal theodolite' was newly made. This shows that Elhe Taifin attaches great importance to astronomy and calendar systems. Those who manage these institutions and conduct observations are all missionaries with strong expertise ${ }^{10}$. In the 9th year of Abkai Wehiyehe (1744), the 'Elaborate Equatorial Armillary Sphere' was newly made and it was presented on stage. However, since then until the abdication of the Qing emperor, the observatory has not added any new equipment. When Yihui was in charge of the Imperial Astronomical Service 钦天监, there were Westerners serving as officials in it. In order to facilitate the supervision and management, he also learned the Latino scripts ${ }^{11}$. In the 1920 s, his descendants stumbled upon a large number of Latin notes and writings while repairing the Yihui cemetery. When Yihui worked at the Royal Astronomical Service, his Western colleagues were all Portuguese. However, he also had many French, Spanish and Russian friends and students. Therefore, the author speculates that Yi Hui's Latin notes are not necessarily limited to one type of writing. This is probably because Yihui deliberately did not tell his family, nor did he mention learning and using Latin in his collection. The author speculates that this must be because Yihui was very sensitive to the political environment and the direction of the empire at that time and was afraid of ruining the family. Yihui often interacted with the Western officials of the Division. He also interacted with Western missionaries in the Catholic Church at ordinary times and was familiar with the Western information at that time. Yihui's friend Gao Shouqian 高守谦, formerly known as Veríssimo Monteiro de Serra, a Portuguese $^{12}$ missionary, he is profesional at astronomy. He living in the East Catholic Church of

\footnotetext{
${ }^{9}$ Author is Unclear who Yihui refers to. Manchu? Han Chinese? Mongol?

${ }^{10}$ Such as Joachim Bouvet, 1656-1730. Domingo Fernández Navarrete,1610-1686. Jean-Baptiste Régis, 1663-

1738. Michel Benoist, 1715-1774. Jan Mikołaj Smogulecki,1610-1656. etc.

11 《荣府家承/奕绘传》: 〈文字学 三〉<钦天监 五〉。 12

乾隆十八年（1753 年）, 葡萄牙传教士傅作霖被授予钦天监监副一职。后从乾隆三十九年（1774 年）至 道光六年（1826 年）的 52 年间，钦天监监正全为葡萄牙人。他们依次是傅作霖、高慎思、安国宁（Anor
} é Rodrigues，1729-1796 年）、索德超（José Bermardo de Almeida，1728- 
Beijing, Ch'ing had once awarded him a senior position in the Royal Astronomical Society. Also, he was appointed to take charge of Beijing North Catholic Church. In the sixth year of Doro Eldengge (1826), he applied to return to Portugal on the grounds that his mother was sick and old. When he was in Beijing, he had close relationship with Yihui. In the 7th year of Doro Eldengge (1827), Yihui wrote a poem <Send Western missionary ShouQian Return to Portugal>.

The following two poems show Yihui's feelings for Serra and his understanding of geophysics at that time:

1, “小坐画堂嗜露酒，旋随高士听风琴，百年始觉天文密，一气能吹乐理深，白发志兴乡国感

，沧溟归弄海潮音。耶稣新教烦相示，千圣同修只此心。”

" We rested with wine in Serra's studio,

Listening to the organ with Serra,

After more than a hundred years, people gradually realized the secrets and mysteries of astronomy.

Serra can talk a lot about music theory,

Serra, who was already gray-haired, suddenly had the idea of returning to his hometown of Portugal.

Those who sailed from far away Europe now have to travel across oceans to return to their

hometowns.

The Protestantism of Jesus is difficult to understand and accept when explained.

However, so many missionaries from the West are dedicated to spreading their religion to the East. "

2, “滔滔阅世指狂流，突壑风波鼓未休，老眼明于千里镜，归帆高过十重楼，下看南极添星座

，渐转西洋绕地球，却笑古人闻见隘，近迁岭表动乡愁。13”

" Appreciating everything in the world is like watching the roaring river,

The storm beats the ridges and mountains, and it never ceases.

The aged eyes can see the distant scenery through the binoculars.

The sailboat Serra was going to take back home, the mast was ten stories high,

It is estimated that standing on the top of the mast can see constellations that have not been seen in the Antarctic sky.

For Serra to return to Western Europe, he must go around the earth and pass through countless seas to get home.

Think about the ignorance of the ancients in the East, without the pioneering spirit of the Westerners, When the ancients of the East went on a long journey, they started to miss home just not far from home."

Although these two poems are short, they contain a lot of information. A young Manchurian nobleman sits in the studio of an old white-haired Portuguese missionary who is proficient in music and astronomy, listening to the melodious melody of the pipe organ while tasting wine. It can be seen that although the two people are very different in cultural background, beliefs, and age, they are already close friends. Moreover, the two can freely exchange opinions and convey ideas, which can also infer that the language exchange between the two should not be limited to the Qing Mandarin at that time.

The poem also mentions that the two people are enjoying music together. Maybe Serra is playing the piano himself, or another luthier is playing. Presumably the two have a lot of common language in music, otherwise Yihui would not listen to Serra's endless talk about music. Know how. In addition to showing Yihui's enthusiasm for astronomy, the poem also reveals that Yihui already possessed the most advanced concept of the earth as a sphere at the time. In addition, Yihui not only

1805 年）、汤士选（Alexandre de Gouveia，1751-1808 年）、福文高（Domingos Joaquim

Ferreira，1758-1824 年）、李拱臣（Jóse Nunes Ribeiro，1767-1826 年）、高守谦（Veríssimo Monteiro de Serra，卒于 1852 年）和毕学源（D. Caetano Pires Pereira， 1763-1838 年）。

13 《明清时期澳门问题档案文献汇编》第 2 册《两广总督李鸿宾奏报已护送西洋人高守谦至澳交夷目收领遇 便搭船回国折》，第 189 页；马士：《东印度公司对华贸易编年史》第 4 卷，第 165 页；《汪若瑟等致葡萄 牙国王书》，《葡萄牙图书馆档案馆藏中文文献：1726-1855》，第 84 页。(Annex 6) 
expressed his resistance to the doctrine of Catholicism, but also praised the pioneering spirit of Western missionaries who traveled far and wide to teach in the East. He believed that Easterners were unwilling to leave their homeland. This information shows that Yihui is comparing, reflecting, and objectively examining himself and Western civilization.

According to Yihui family history document, as Yihui is professional in Western civilization, while learning from missionaries, Yihui had many Western students from different countries, all of whom had their own specialties, came from different churches, and some were sent by the church. others sent by the Western government. Each student has detailed information and biographies. During the holidays or new year days, these Westerners who were given Chinese names by Yihui have to visit Yihui. This shows the level of contact between Yihui and Westerners in Beijing at that time. This has a significant impact on his academic attainments and acceptance of Western cultural technology.

\section{《明善堂集·流水编八》〈哭九儿载同〉}

“秦公识晚老潘没, 过信庸医读父经。”

"Mingshantang Collection/ Chapter Eight of Flowing Water" < Cry the ninth son, ZaiTong. > "It was too late to get to know Mr. Qin, a Russian doctor of western medicine with superb medical skills, that my child's life could not be saved.I am just too confused and over-trust the quack doctor who will only follow the famous doctor's father to make a diagnosis! "

Since Yihui's cutest son Zaitong was misdiagnosed by a quack and died, Yihui began to firmly choose Western medicine. Yihui's selection and exposure to Western medicine also provides certain resources for future generations to learn and apply Western medicine diagnosis in depth.

\section{Section 5}

Yihui advocates that Western learning should be adopted, but he still attaches great importance to Eastern traditional culture. In the two poems of " Mingshantang Collection and Chapter of Flowing Water I《明善堂文集 流水编一》", he encouraged future generations to inherit the four family studies of Chinese, Horsing archery, Manchu language, and algorithm. Also, he suggested insisting on inheriting it as a habit. Hope youth don't forget the original family studies and don't throw it away. Here are two poems in Ch'ing official language and algorithm:

“大清爱建国，天命始为书，地据三韩旧，言犹渤海余，诹咨通训诂，问学辨虫鱼，继志勿忘

本, 生民各有初。”

\section{$\langle$ Translation〉}

"Dacing (our worriors) found the Empire,

Manchu was created in the era of Abkai Fulingga(1616-1626),

Our motherland is based on the original north Korea penisula, so called the old three Korean Kin There are still morphemes from the Bohai Kingdom in our language.,

Our language is closely related to these ancient languages,

Inheriting and learning these cultural, historical and language knowledge can enable us to understand our origin and better understand ourselves and everything in the world,

Inheriting the ancestors, don't forget our cultural attributes,

Different group cultures have their origins."

Linguistics is an important part of Prince Hošoi derengge's family studies and combining linguistics to study the national history is a major feature of family studies. Therefore, the descendants of Prince Hošoi derengge's family not only inherited the Manchu-Mongol Chinese literature and Manchu-Mongol linguistics, but also Going deep into the study of Jurchen and Khitan, to the great grandson of Yihui, Hengxu, also, the fifth grandson JinQiZong, and the sixth grandson Ulhichun all became historical linguists. They research on Manchu, Jurchen, Khitan, Manchu Studies, Mongolian history, Liao and Jin history, Ch'ing history research works, etc. 
“算有西来法, 亲承祖父传, 变通时考证, 悟诣遂精专, 九曜天文密, 元音字母全, 术深久恐

失, 思作本形篇。”

<algorithm>

"There are calculation techniques from the West in the algorithm,

I inherited the teaching from my grandfather and father,

Accepting the notion that foreign things need to be flexible, but also to research it from time to time,

Only in this way can we comprehend its truth and gradually become proficient in this technique,

The nine planets of the solar system are infinitely mysterious,

The vowels of Western languages have a strong phonetic coverage,

I am worried that this algorithm research will be lost in the future,

So, I wrote this article to leave to the future generations. "

From the above poems, we know that the three generations of Prince Hošoi Derengge family are all proficient in algorithms; and the algorithm of Yihui is inherited from his father and grandfather. Because YongKi was loved by Emperor Abkai Wehiyehe, he could stay in the palace and grow up. The enthusiasm of the first three emperors for Western civilization made it easy for the princes to come into contact with a lot of Western civilization and knowledge in the Forbidden City. Yongki officially had such a unique growth environment that he achieved certain achievements in the study of Pythagorean theorem, which was discussed when Emperor Abkai Wehiyehe borrowed from the British envoy many years after Yongki's death. It can be seen that Yongki's mathematical accomplishment is not superficial.

(乾隆四十八年十月初二日)......朕视皇五子, 于诸子中觉贵重 ; 且汉文、满洲、蒙古语、马 步射及算法等事, 并皆娴习。颇属意于彼而未明言。乃复因病旋逝。”

(The second day of October, forty-eight years of Abkai Wehiyehe)

... "I think the fifth son is the most outstanding among the princes; and he is very skilled in Chinese, Manchurian, Mongolian, cavalry and shooting, infantry shooting and hunting, and algorithms. I really want to choose him as the crown prince, but I didn't say clearly. Unfortunately, he passed away suddenly.'

At the end of the Ch'ing Dynasty, the Prince Hošoi Derengge family Palace at that time was dominated by the Duke PuYun. ${ }^{14}$ Because PuYun's wife Suwan Guwargia's elder brother YanLing was a diplomat, the Duke PuYun's family was familiar with the officials of the embassies in Ch'ing at that time. Sometimes when the former diplomat resigned, they introduced their successor to PuYun family before they leave. PuYun family and foreign friends teach language and culture to each other. Due to the introduction of foreign friends, family members were familiar with the latest astronomy, geography, and scientific knowledge in the world. The younger two generations of the family, Duke PuYun's nephew, YuJian, PuYun's twelfth sister, and PuYun's son Heng Xu, are all fluent in English and German and were active in the Active in education and research. ${ }^{15}$

During the Badarangga Doro reign, Duke PuYun's wife SuwanGuwargia JianNian was influenced by the Westernization Movement and began to pay attention to women's education. Learning from the new education model, she founded a Lady's school in Beijing called the NvZiChuanXiSuo 女子传习所. She was the honorary principal and the principal was her daughter-inlaw Dengiya Heping. The address is located in PuYun's Palace. The textbook "The Model of Female Family《女子家庭模范》" of the Lady's School was written by SuwanGuwargia JianNian herself. The women's school and the textbooks compiled by her seem to be nothing new today, but it was an extremely new style for Manchu in Beijing a hundred years ago. It was written by popularizing traditional East Asia women's morals. There is also a western cooking class in the course, and the teacher is hired by the priest from the American church to teach. At that time, many young women came to sign up to study this school. These female students are mostly bureaucratic ladies of the

\footnotetext{
${ }^{14}$ kesi-be tuwakiyara gurun-be dalire gung, which means the Duke Who Receives Grace and Guards the State.

${ }^{\mathrm{R}}<$ 荣府家承 $>$ 芸公传,西学篇。
} 
Ch'ing and later Republic of Ch'ing. The enthusiasm for learning is very high, so that this school was very famous in Beijing. From Gehungge Yoso period to the Republic of China, it has existed for six years (1907-1913) . At that time, the Han Chinese revolutionary forces in the south had given affirmation to this lady's school. The wife of Vice President LiYuanhong 黎元洪 of the Republic of Ch'ing and wife of the RuanZhongShu 阮忠枢, the Secretary General of the Presidential Office and the Confidence of Yuan Shikai 袁世凯, have also visited the PuYun Palace frequently. This school have a certain status in the history of education in later Ch'ing history, especially in the history of women's education and Beijing's education.

Yogiyan, PuYun's nephew, was influenced by Western learning and determined to study law and western medicine when he was young. When Prof. JinQiZong was young, he could still see books such as "General Theory of Law《法学通论》" left by Yogiyan ${ }^{16}$. There are many books on western medicine, including books on internal medicine, surgery, and gynecology. The famous "Dermatology Treatment《皮肤症治》" is a colorful painted dermatology book, which contains color pictures of various skin diseases. JinQiZong still remembers the fear of reading when he was young. Yogiyan has professional in Western medicine. Yogiyan studied medicine and treated diseases and administer medicine for the local peoples of west countryside of Beijing where he lived. Whenever the nearby villages had colds and fevers, he went to seek witchcraft, and tried to heal. Yogiyan treated it with "quinine pill", and patients recovered in few days and surprised. Yogiyan went to the public for diagnosis and treatment and did many volunteers medicine support to the local people. Yogiyan has a

Britain doctor friend. Because of joint medical research, they are good friends. In the early years of the Republic of Ch'ing, Moore open a hospital and hired Yogiyan as a physician in the hospital.

\section{Conclusion}

From the time of Emperor Abkai Wehiyehe, most royal families are mediocre, which is related to the rule of Emperor Abkai Wehiyehe. The inner city of Beijing is not only an independent living space for Manchurians, but also a concentration of embassies and churches of various sects, which gives the Manchu nobles and Westerners more opportunities to contact. The Prince Hošoi Derengge family Palace humbly learned Western technology and culture, introduced traditional Ch'ing culture to the Westerners, actively established schools, learned Western language, recognized and practiced Western medicine, and promoted advanced Western learning It It became a very special academic aristocratic family in the middle and late Qing Dynasty and played a role in open cultural exchanges.

Because the Ch'ing Empire did not have the system of set feudal vassals from other provinces as Ming or other Chinese authorities did, All members of the royal family and the emperor live in the inner city of Beijing, and no royal family members are allowed to leave the capital without authorization from the emperor. The living environment of the Royal Observatory in the Qing Dynasty is a basic platform for mutual learning and cultural exchanges with Westerners. People like Yihui and Mingant make full use of this platform to communicate with Westerners in depth. This communication is bound to affect Yihui's descendants, in addition to absorbing the West in civilization, each generation of children and grandchildren can also have their own specialties, such as mastering English and German, using Western medicine to treat local patients, opening new schools, and actively referencing Western academic research results for comparison even in the research of social sciences and natural sciences. The introduction of Western medicine of YuMin, especially the promotion of private Western medicine, brought well-being to the general public and was a manifestation of social progress at that time. What's more commendable is that he is a nobleman.

After the Second Opium War (1860), Ch'ing was becoming to a semi-colonial and semifeudal country. The role of missionaries in Ch'ing has undergone a great change, from the previous use of scientific knowledge to assist missions to more fields. Such as education and medical services, participation in political activities, etc.; establish orphanages and church schools in Ch'ing; many

\footnotetext{
${ }^{16}$ The Prof. JinQiZong is the 8 generation descendants of the family. $\langle$ Qizong Collected Works $\rangle\langle$ family history $><$ Yogiyan $>$ page 2 .
} 
famous universities are run by Western churches; the earliest Western medical hospitals are also run by Western churches; Western churches also run newspapers, Magazines and other media promoted press freedom in the late Ch'ing. Western culture has shaken the foundation of the old culture of the Ch'ing Dynasty even in any period of history. Due to the role of this cultural exchange work, Western priests, diplomatic missions, businessmen and foreign students are active in many fields.

Although the Yihui family is not the central decision-making figure of the Manchurian Empire, they have always accepted Western civilization, understood the world, and made foreign friends in all ages. The author believes that perhaps it is because of the special status and superior conditions of the prince that the Yihui family can, while learning to master Han cultural civilization, objectively and rationally examine the self as a minority of rulers from outside, and develop a broad mind to embrace Western civilization. Of course, the formation of such a family in the Qing imperial royal family is itself a subject worthy of consideration.

Yihui's thinking clearly recognizes the shortcomings of Eastern culture and civilization. He did not protect traditional astronomy or medicine. Oppositely, Yihui pointed out the importance of Western learning through sharp contrast. Unfutunately, because of his social status, he can only liberate and enrich himself and his family. This ideology has also been passed on to his descendants.

\begin{abstract}
Annex 1
1 ,《乾隆御制诗集》4 集，卷 93 ，癸卯 1 ，《题宋版周骿算经》。“皇祖精明勾股弦，惜吾未习值髺 年。而今老固难为学, 自画追思每愧旃。”
\end{abstract}

$2, 《$ 高宗纯皇帝实录》乾隆十五年十月丁丑日(November 6, 1750)

我滿洲本業。原以馬步騎射為主。凡圍獵不需鳥鎗。惟用弓箭。即索倫等圍獵。從前并不用鳥鎗。 今聞伊等、不以弓箭為事。惟圖利便。多習鳥鎗。夫圍獵用弓箭。乃從前舊規。理宜勤習。况索倫 等皆獵獸之人。自應精於弓箭。故向來於精銳兵丁內、尤稱手快。伊等如但求易於得獸。久則弓 箭舊業。必致廢弛。將此寄知將軍傅爾丹、令其嚴行傳諭索倫等。此後行圍。務循舊規。用弓箭 獵獸。將現有鳥鎗。每鎗給銀一兩。臬行收回。想伊等鳥鎗。亦有來處。并非自造。今既行禁止。 必須察明實數收貯。著傅爾丹上緊留心察收。收回後、嚴禁偷買自造。查出即行治罪。仍曉諭索 倫等、今收回鳥鎗者。特因爾等圍獵。不用弓箭。習學鳥鎗者過多。皇上欲爾等不棄舊規。仍復本 業。爾等應體皇上憐憫訓導至意。凡遇圍獵。母用鳥鎗。仍前專用弓箭。務復舊習。不但超列優等 。而善馬步射者。可被恩梸用侍衛等官。將此明白曉諭之。

In English:

On the dingchou day of the 10th month of the 15th year of the Qianlong reign (November 6, 1750), the emperor issued the following edict :

The original vocation of we Manchus focused on riding horses and shooting. Ordinarily, in hunting, we had no need for guns, and only used bows and arrows. Previously, when the Solon hunted in a battue, they never used guns. Now I hear that they do not do things using bows and arrows anymore, but instead seek what is convenient, and have generally become accustomed to using guns. The use of the bow and arrow in hunting is a longstanding custom, and a principle suitable to diligent practice. Moreover, the Solon are hunters, and certainly should be proficient in archery; for this reason, among our crack troops, they have always been especially commended for their skill. If they think only about obtaining game the easy way, with time their traditional archery skills will certainly weaken. Send this to General Furdan and order him to rigorously convey this edict to his Solon men. Henceforth when mounting a battue, they must abide by the old rules and use bow and arrow to hunt game. For each gun currently in their possession, give them one tael of silver; collect them all without exception. My thinking is that these guns must also come from their own sources, since [the soldiers] certainly do not make them themselves. Now, once the prohibition has been implemented, we must ascertain clearly the actual number [of these weapons] and store them securely. 
Let Furdan take extreme care in counting and collecting them. After they have been collected, strictly prohibit their illicit purchase and production, and ferret out and promptly punish violators. In addition, issue explicit instructions to the Solon: "The reason we are now collecting your guns is particularly because in hunting too many of you do not use bows and arrows, but instead are learning to use guns. His Majesty desires that you not abandon your old ways, but return to your original vocations. You all should follow the example of His Majesty's compassionate guidance and sincere intention: when you go to hunt in battue, do not use guns, but, as before, use bow and arrow; you must return to the old customs. Those who not only excel [at archery] but also adeptly shoot from horseback can receive the favor of being raised to official ranks like Imperial Guardsman." Use this to clearly instruct them.

In the 25th year of Emperor Qianlong (1760), the missionary Michel Benoist 蒋友仁 produced a "Supplementary Kun Yu Quan Tu". In the explanation of this picture, Jiang Youren made it clear that Copernicus's heliocentric theory was the only correct one, and introduced Kepler's three laws and some recent developments in European astronomy, such as the earth's oval shape. "Additional Kunyu Quantu" was dedicated to Qianlong as a birthday gift. Although Qianlong happily praised Jiang Youren and rewarded him with a few pieces of silk, he did not understand the value of this picture. As a result, this picture was locked in the palace's inner courtyard, and no one knew it.

\section{Annex2}

The Catalan sequence was described in the 18th century by Leonhard Euler, who was interested in the number of different ways of dividing a polygon into triangles. The sequence is named after Eugène Charles Catalan, who discovered the connection to parenthesized expressions during his exploration of the Towers of Hanoi puzzle. The counting trick for Dyck words was found by Désiré André in 1887. What is unexpected is that Catalan numbers in Mingantu 明安图's book The Quick Method for Obtaining the Precise Ratio of Division of a Circle volume III by 1730 . That is when he started to write his book Ge Yuan Mi Lu Jie Fa [The Quick Method for Obtaining the Precise Ratio of Division of a Circle]《割園密率捷法》, which was completed by his student Chen Jixin in 1774 but published sixty years later.

(P.J. Larcombe. The 18th Century Chinese Discoery of the Catalan Numbers. 1999/2000 Volume32 Number1) However, Larcombe may not know much about history and culture, so in his article Minggantu was used to disassemble the name of Chinese Han style into Antu Ming, and Larcombe's article also used the word 'Chinese', indicating that the author did not understand Minggantu Mongolians Identity and relations between Manchuria and Mongolia during the Qing Dynasty. Minggantu is a Banner Man, His name first appeared among the official document of Imperial Astronomical Bureau in 1713, From 1724 up to 1759, he worked at the Imperial Observatory.

( http://www.mongolinternet.com/famous/MyangatBiography.htm)

\section{Annex 3}

1 , 《圣祖仁皇帝实录》康熙四十八年三月初九日, 扸礽重立为太子。尔后, 康熙加封诸子, 皇三 子扸祉、皇四子扸䄍、皇五子扸祺俱著封为亲王, 皇七子扸祐、皇十子扸袐俱著封为郡王, 皇九 子扸裾、皇十二子乣祹、皇十四子扸禎俱着封为贝子。未受封爵的成年皇子只有已遭囚禁的皇长 子胤禔、皇十三子乣祥与大失圣心的糺禩。

2 ,《世宗宪皇帝实录 卷之四十五》雍正四年六月三日，(八阿哥)听信相士张明德诖言遂欲谋杀二 阿哥, 希图储位, 又与大阿哥暗蓄刺客, 谋为不轨, 众所共知者一也。

3, 《世宗宪皇帝实录 卷之四十》雍正四年正月五日, 从前皇考曾谕诸王等 : 允禩奸险诡计, 结 党设谋, 欲弑皇太子, 今事俱败露, 见在交审。是时允裾允嘎在侧, 独挺身保奏允禩并无此意 ，因致皇考震怒，拔刀欲诛允禎，恒亲王等劝止，将允禎责惩，并允裾逐出。

4 , 《圣祖仁皇帝实录》康熙四十七年十月二日, 布穆巴供 : 张明德往普咅公家, 回至我府, 言 普妾谓皇太子甚恶与彼谋刺之约我入其伙, 我不从, 故以语直郡王(胤禔)。直郡王(胤禔)云 : 尔 
勿先发此事，我当陈奏可受此人，送至我府，因送往直郡王府...九阿哥胤禟、十四阿哥胤祦供 : 八阿哥曾语我等, 有看相人张姓者云皇太子行事凶恶已极, 彼有好汉可谋行刺, 我谓之曰此 事甚大，尔何等人乃轩敢出口? 尔有狂疾耶? 尔设此心，断乎不可，因逐之去。八阿哥胤禩供： 我以此语告诸阿哥是实，问张明德口供无异。取供具奏，上谕诸皇子议政大臣大学士九卿学士 侍卫等曰：贝勒胤禩闻张明德如许妄言，竟不奏闻，片禩革去贝勒为闲散宗室。...公普竘知情 不首, 革去公爵, 为闲散宗室。...张明德情罪极为可恶, 著凌迟处死行刑之时, 可令事内干连 诸人往视之。

\section{Annex 4}

1 ,《圣祖仁皇帝实录》康熙四十八年正月二十二日，康熙帝谕满汉诸臣曰：...所以拘执皇太子( 胤礽)者，因其获戻于朕耳，并非欲立胤禩为皇太子而拘执之也。皇太子(扸礽)获罪之处虚诬者 甚多。今马齐、佟国维与胤禔为党, 倡言欲立胤禩为皇太子, 殊属可恨, 朕于此不胜忿恚, 况 胤禩乃缧绁罪人、其母又系口族，今尔诸臣乃扶同偏徇保奏胤禩为皇太子，不知何意? 岂以胤 禩庸劣无有知识, 倘得立彼则在尔等掌握中, 可以多方簯弄乎? 如此则立皇太子之事皆由于尔 诸臣、不由于朕也，且果立胤禩，则胤禔必将大肆其志，而不知作何行事矣！朕悉睹其情形， 故命亟释废太子胤礽。朕听政四十九年包容之处甚多，惟于兹事忿壳殊甚，朕原因气忿成疾... 。谕曰：马齐原不谙事, 此数年中起自微口, 历升至大学士, 其处心设虑无耻无情但务贪得, 朕知之已久早欲斥之, 乃潜窥朕意而蓄是心殊为可恶, 理应立斩, 以为众戒, 朕因任用年久不 忍即诛, 著即交胤禩严行拘禁。李荣保著免死, 照例枷责, 亦听胤禩差使。马武著革职, 其族 中职官及在部院人员，俱革退，世袭之职亦著除去，不准承袭。…

2 , 《圣祖仁皇帝实录》康熙五十三年十一月，康熙帝谕诸皇子：“胤禩系辛者库口妇所生，胤禩自 幼心高阴险, 听相面人张明德之言, 遂大背臣道, 受人谋杀二阿哥胤礽, 举国皆知, 胤禩杀害 二阿哥胤礽, 未必念及朕躬也。朕前患病, 诸大臣保奏八阿哥胤禩...仍望遂其初念与乱臣贼子 等结成党羽密行险奸, 谓朕年已老迈岁月无多及至不讳, 伊曾为人所保, 谁敢争执, 遂自谓可

保无虞矣, 朕深知其不孝不义情形, 即将所遣太监冯遣朝等于朕所御帷幄前, 令众环视, 逐一 夹讯，伊已将党羽鄂伦岱、阿灵阿尽皆供出。自此，朕与八阿哥胤禩父子之恩绝矣，朕恐后日 , 必有行同狗㱜之阿哥仰赖其恩为之兴兵构难, 逼朕逊位而立八阿哥胤禩者, 若果如此, 朕惟 有含笑而殁已耳, 朕深为愤怒。特谕尔等众阿哥, 俱当念朕慈恩遵朕之旨, 始合子臣之理。不 然, 朕日后临终时必有将朕身置乾清宫, 而尔等执刃争夺之事也, 扸禩因不得立为皇太子恨朕 切骨, 幻禩之党羽亦皆如此”。

\section{Annex 5}

A, De re metallica. 《坤與格致》1643. Chinese version.

B, Ferdinand Verbiest《欧洲天文学》（Astronomia Europea） one volume.1687. Chinese version.

C, Ferdinand Verbiest《测验纪略》1669. one volume. Chinese version.

D, Ferdinand Verbiest《御览西方要纪》1669. one volume. Chinese version.

E, Ferdinand Verbiest《仪象志》(Yixiang zhi), 1673 (on astronomical instruments and apparatus. Chinese version. 
F, Ferdinand Verbiest《康熙永年历法》(Kangxi Yongnian Lifa), 1678 .On the calendar of the Kangxi Emperor.

G, Ferdinand Verbiest《方言教要序论》(Jiaoyao xulun) explanation of the basics of the faith.

H, Kunyu Quantu《坤與全图》. 1674. was a map of the world developed by Jesuit father Ferdinand Verbiest during his mission in Ch'ing. etc.

I, Jean Baptiste Regis. Y - King. Antiquissimus Sinarum liber quem ex Latina interpretatione P.

Regis aliorumque ex Soc. Jesu. P. P. edidit. J. Mohl...Cum quatuor tabulis. 2 vol. Stuttgartiae et Tubingae, 1834-1839, 《拉丁文版易经》Latin version of 〈I Ching>.

J, Jan Mikołaj Smogulecki《天步真原》3 Volume. introducing logarithms to the Ch'ing empire.

K, Domingo Fernández Navarrete. 1676. Tratados historicos, politicos, ethicos, y religiosos de la monarchia de China: Descripcion breve de aqvel imperio, y exemplos raros de emperadores, y magistrados del. Con narracion difvsa de varios svcessos, y cosas singvlares de otros reynos, y diferentes navegaciones. Añadense los decretos pontificios, y proposiciones calificadas en Roma para la mission chinica; y vna bula de N.M.S.P. Clemente X. en fauor de los missionaries.

\section{Annex 6}

1 ,清道光七年（1827 年 1 月 27 日-1828 年 2 月 14 日） 7 月 23 日，因嘉庆帝的禁教影响，钦天 监副葡萄牙遣使会会士高守谦因其母年老，呈请回国终养，于本日返抵澳门。俟有便船即令附 搭回国。《明清时期澳门问题档案文献汇编》第 2 册《两广总督李鸿宾奏报已护送西洋人高守谦 至澳交夷目收领遇便搭船回国折》，第 189 页 ;

2 ,马士 : 《东印度公司对华贸易编年史》第 4 卷，第 165 页称高守谦为“在北京的最后一位罗马 天主教传教士”，又称其抵达澳门的时间为 7 月 1 日，均有误。另，据北京教友汪若瑟言：“高 守谦之所以辞职是因为南京主教毕学源、署理北京主教李拱辰与澳门圣若瑟修院诸神父串通诬 证高守谦神父不良，被同会会士排挤。因为当时葡萄牙国欲保举高氏为北京主教，故“买嘱不 肖之徒说谎妄证，陷害先王所保举北京主教高物利西默（即高守谦）为不良”。

3, 高守谦“见伊等不服，如此恶行恶表，难以挽回，亦难于势争，是以退位自藏。”汪若瑟等致 葡萄牙国王书》，《葡萄牙图书馆档案馆藏中文文献：1726-1855》，第 84 页。

\section{Reference}

Y - King. Antiquissimus Sinarum liber quem ex Latina interpretatione P. Regis aliorumque ex Soc . Jesu. P. P. edidit J. Mohl...Cum quatuor tabulis. 2 vol. Stuttgartiae et Tubingae, 18341839 ,

Herbermann, Charles, ed. 1913. "Jean-Baptiste Régis". Catholic Encyclopedia. New York: Robert Appleton Company

Larcombe, Peter J. "The 18th century Chinese discovery of the Catalan numbers"

Luo Jianjia. Ming Antu, the First Inventor of Catalan Numbers in the World. Institute for the History of Science Nei Monggol Normal University

Bartlett, Beatrice S., 1991, Monarchs and Ministers: The Grand Council in Mid-Ch'ing China, 17231820, Berkeley and Los Angeles: University of California Press.

Wu, Silas H. L., 1970, Communication and Imperial Control in China: Evolution of the Palace Memorial System, 1693-1735, Cambridge: Harvard University Press.

宮崎市定 1950『雍正帝』岩波新書、中公文庫、復刊 1996 年

《荣府家承》<奕绘传〉 
МРНТИ 03.01.13 